\title{
ResenHa/Book Review
}

\section{O país do Amazonas}

Marilene Corrêa da Silva

Manaus: Editora Valer / Governo do

Estado do Amazonas / UniNorte, 2004.

Amazônia: geopolítica na virada do III milênio

Bertha Koiffman Becker

Rio de Janeiro: Garamond. 2004.

\section{O PAÍS DO AMAZONAS NA VIRADA DO III MILENNIO NA VOZ DE DUAS MULHERES}

\section{TATIANA SCHOR *}

Duas leituras diferentes, porém não destoantes, nem distantes, são apresentadas por duas mulheres que, há muitos anos, analisam a Amazônia por dentro da tradição das ciências sociais. As duas vozes, em conjunto, elaboram novas perspectivas analíticas para aqueles que buscam entender o longo e tortuoso processo de incorporação da Amazônia no território nacional. Um debate importante e interessante de ser acompanhado não só pelo viés ambientalista ou ecologista, mas também pelo viés das ciências sociais.

Marilene Corrêa, em seu livro O país do Amazonas, faz uma história política dos conflitos e usos do território desta vasta região que convencionamos chamar de Amazônia, com seus diversos adjetivos (legal, brasileira, bacia). A autora, dispondo de um conjunto documental, de dissertações e teses produzidas em todo

* Economista, doutoranda do PROCAM/USP e professora do Campus Universitário SENAC - Santo Amaro. território brasileiro, re-descobre de maneira sociológica a história dos diversos conflitos que conformam esta parcela de nosso território. E, como cabe a uma cientista social, vincula esta história política às discussões clássicas da formação econômica e social do Brasil, principalmente, à vertente de Fernando Novais e Otavio Ianni.

Para realizar essa análise, a autora constrói três recortes analíticos: a Amazônia Lusitana/Portuguesa, a Amazônia Indígena e a Amazônia Brasileira, e conduz o leitor por trajetos da história dos diversos conflitos, delineando possibilidades de leitura do passado que permitem diversas entradas para compreender as diversas realidades sócio-políticas da Amazônia deste começo de século. Embora a autora tenha feito uma análise cronológica, ela permite, porém, um confronto não linear dos acontecimentos, isto é, dos principais conflitos entre as populações sujeitas ao processo de constituição da modernidade e os detentores do poder sobre esses processos. Procedendo a uma análise que vai da subsunção do trabalho e dos conflitos étnicos no período de coleta das drogas do sertão, da constituição das missões e das diversas tentativas de domínio físico sobre o território à cabanagem, ao ciclo da borracha e aos diversos setores da luta pela Independência do Brasil no Grão-Pará, a autora chega à conclusão de que " $a$ conquista e a colonização da Amazônia sempre suscitaram procedimentos excepcionais da Coroa e do Estado português" (269), configurando, com isso, as excepcionalidades com as quais ainda é necessário lidar para se entender e internalizar esse território na discussão 
sobre a nação. As conseqüências da repressão à Revolução Cabana e o entendimento por parte do estado nacional de que essa região é frágil, faz com que o Estado, na visão da autora, manipule "com o discurso da soberania, da integridade da Nação, da unidade territorial" (277) as relações entre a região e a nação.

De fato, o discurso da soberania, da integridade nacional e da unidade territorial permeia as diversas frentes de ação política na região, configurando o que Bertha Becker discute em Amazônia: geopolítica na virada do III milênio. No seu primeiro capítulo, o livro de Bertha parte, de maneira sucinta, do Legado Histórico da região, analisa as mudanças estruturais que ocorreram no final do século XX e discute como estas mudanças e a incorporação deste território no processo de globalização permitem pensar uma nova geografia da Amazônia. O discurso sobre o domínio do território, na forma de um discurso geopolítico de soberania nacional, pauta, como nos mostra Bertha, grande parte das opções de políticas públicas para a região. Não só na ocupação do território, mas principalmente com relação aos seus usos, a necessidade do domínio sobre a natureza, desde a constituição de áreas protegidas até as pesquisas de bioprospecção, fica sob suspeita, pois, parte-se da premissa de que a soberania nacional está sempre ameaçada.

Bertha permeia esta perspectiva com discussões acerca das falácias sobre a compreensão do território e da nova realidade que constitui o tecido da região. São as diversas redes - das cidades, da pesquisa e do capital natural - que reconfiguram a Amazônia, não mais como uma fronteira, mas como várias fronteiras. Dessa discussão, redefine o conceito de fronteira, que deixa de ser espaço não plenamente estruturado e passa a ser um espaço de projeção para o futuro. Sem dúvida, é o País do Amazonas na virada do III milênio o espaço da dúvida sobre como será o futuro: quem sabe, sócioambientalmente diferente. 